Published in final edited form as:

Curr Pharm Des. 2017 ; 23(28): 4170-4179. doi:10.2174/1381612823666170208123553.

\title{
Adiponectin as a Potential Therapeutic Target for Prostate Cancer
}

\author{
Hanuma Kumar Karnati ${ }^{1,{ }^{*}}$, Manas Kumar Panigrahi ${ }^{2}$, Yazhou Li $^{1}$, David Tweedie ${ }^{1}$, and Nigel \\ H. Greig ${ }^{1,{ }^{*}}$ \\ ${ }^{1}$ Drug Design \& Development Section, Translational Gerontology Branch, Intramural Research \\ Program, National Institute on Aging, National Institutes of Health, Baltimore, MD, 21224, USA \\ ${ }^{2}$ Department of Neurosurgery, Krishna Institute of Medical Sciences (KIMS), Hyderabad- 500003, \\ Telangana, India
}

\begin{abstract}
Adipokines are bioactive proteins that mediate proliferation, metabolism, inflammation, and angiogenesis. Adiponectin is an important adipokine that exerts multiple key functions via its antimetabolic syndrome and anti-inflammatory properties. A number of adiponectin receptors, AdipoR1, AdipoR2 and T-cadherin, have been identified. Recent studies have suggested the involvement of adiponectin and receptors in several cancers, including prostate, breast, endometrial, brain, and colon cancer. Altered levels of adiponectin expression, or its interacting receptors, in cancers can lead to dysregulation of signaling pathways. Our current review describes the molecular mechanisms underlying the anti-tumorigenesis activity of adiponectin and the role of its receptors in prostate carcinogenesis, and provides perspectives of adiponectin-mediated signaling as a potential target for therapy.
\end{abstract}

\section{Keywords}

Adiponectin; cancer; obesity; AdipoR1; AdipoR2; T-cadherin

\section{INTRODUCTION}

Prostate cancer is the second most prevalent cancer afflicting men, and whereas it manifests in middle-aged and older males throughout the world [1-3], it is a particularly important health concern in North America and Western Europe [4]. High fat and high calorie dietary customs, in addition to a sedentary lifestyle, are key risk factors in the pathogenesis of prostate cancer. Studies also suggest that dietary fat and total energy intake are important determents of prostate cancer [5]. Excess weight in obese patients associated with abnormal

\footnotetext{
*Address correspondence to this author at the Drug Design \& Development Section, Translational Gerontology Branch, Intramural Research Program, National Institute on Aging, National Institutes of Health, Baltimore, MD, 21224, USA; hanuma.karnati@nih.gov; greign@mail.nih.gov.

CONSENT FOR PUBLICATION

Not applicable.

CONFLICT OF INTEREST

The authors declare no conflict of interest, financial or otherwise.
} 
adipose tissue deposition could lead to abnormal secretion of adipocytokines, inflammation, insulin resistance and impact the biosynthesis and bioavailability of endogenous sex hormones. Indeed, overweight and obesity are known key risk factors for several cancers (including colon, esophagus, kidney, and pancreatic), as well as that of the prostate [6], and additionally raise the risk for heart disease and diabetes. Individuals with a high Body Mass Index (BMI) are associated with increased risk of cancer. Indeed, a role of BMI in the pathogenesis and mortality of prostate cancer has been repeatedly described [6, 7]. The links between obesity and prostate cancer are complicated, as increased risks likely stem from social as well as biological stimuli because obesity is influenced by a variety of effects, including genetic factors and environmental exposures. Several epidemiological studies support obesity as a risk factor for prostate cancer [8-10]. One study showed that abdominal obesity is a major risk for benign prostatic hyperplasia [10]. The molecular mechanisms underpinning its pathogenesis remain unclear despite extensive research. Recent studies have provided evidence that adipose tissue-derived cytokines may play a role in the link between obesity and prostate cancer. Adiponectin belongs to the group of proteins termed 'adipokines' that are generated and secreted from adipose tissue into the bloodstream to influence many physiological processes including glucose and lipid metabolism, inflammation and reproduction. An inverse association between the levels of adiponectin and insulin resistance has been suggested to provide a risk factor for prostate cancer [11]. Diminished adiponectin levels have been reported in some cancers in addition to type 2 mellitus (T2DM), obesity, and cardiovascular disease [12]. Reports of the inverse association between adiponectin levels and risk of cancer have now been extended to renal, breast, endometrial, gastric and prostate cancers [11, 12-27]. Specifically, adiponectin levels are lower in the plasma of patients with prostate cancer than in normal healthy controls and those with benign prostatic hyperplasia. In line with this, adiponectin receptor levels are likewise less in resected prostate cancer tissues [25, 28, 29]. By contrast, the elevation of adiponectin levels may have a key role in suppressing prostate cancer cell development. The over expression of adiponectin in prostate cancer cell lines is reported to inhibit cancerous cell growth, and appears to be mediated via mammalian target of rapamycin (mTOR) signaling pathway activation of Vascular Endothelial Growth Factor A (VEGF-A) [30]. MicroRNA 323 has been demonstrated to promote VEGF-A-mediated vascularization in prostate cancer cells through inactivation of AdipoR1 [31]. In synopsis, current studies suggest that a decline in circulating adiponectin, whether a consequence of genetic factors, diet, abdominal adiposity and physical activity, represents a risk factor for as well as potential diagnostic/prognostic biomarker for prostate and quite possibly other cancers. Furthermore, adiponectin and therapeutic strategies that up-regulate signaling pathways downstream of adiponectin may prove to be useful in suppressing tumor growth.

\section{ADIPONECTIN}

Adiponectin is an adipocyte-derived hormone that was identified in murine and human adipocytes [32-34]. It is encoded by the $A P M 1$ gene (adipose most abundant gene transcript1) that comprises three exons that span $163 \mathrm{~kb}$ and is localized on the long arm of chromosome 3 within the $3 \mathrm{q} 27$ region that, interestingly, is closely associated with quantitative trait loci for T2DM and metabolic syndrome. Recent studies have acknowledged

Curr Pharm Des. Author manuscript; available in PMC 2018 March 01. 
the presence of adiponectin in other tissues, including osteoblasts, myocytes, liver parenchyma cells, placental tissue and epithelial cells [33,35-40]. This protein exists in the form of 30-kD monomeric subunits (Fig. 1) that possess an N-terminal collagenous domain and a globular head that is structurally related to complement factor $\mathrm{C} 1 \mathrm{q} / \mathrm{Tumor}$ Necrosis Factor (TNF)-family proteins [32, 41-43]. Adiponectin naturally exists in the form of multimers, for which all forms appear to be biologically active. Generated as a monomer, it is then assembled into a number of forms that include low molecular weight trimers, medium molecular weight trimer-dimers (hexamers), as well as High Molecular Weight (HMW) adiponectin (Fig. 1) before secretion. HMW-adiponectin appears to be the physiologically most relevant and dominant form of adiponectin in plasma. Serum adiponectin is associated with increased insulin sensitivity, reduced abdominal fat, and high basal lipid oxidation rate; however, it appears to be the HMW quantity, rather than the total protein levels, that is primarily responsible for these relationships. Furthermore, reduced quantities of HMW-adiponectin have been reported to independently provide the lipoprotein subclass profile that is allied with insulin resistance, even following appropriate adjustment for the glucose disposal rate and BMI [44, 45]. These studies indicated that altered levels of HMW-adiponectin are indicative of and can be utilized as a marker for disease-associated adipocyte dysfunction [44, 45]. One study also suggests that lowered HMW-adiponectin levels can predict endothelial dysfunction [46]. A broad number of elements, including nutrition, inflammatory status, genetics and post-transcriptional modifications appear to have a role in the regulation of adiponectin levels [45, 47, 48]. A sexual dimorphism has been reported in relation to adiponectin multimers in mice and human. Males have been described to have more trimers, whereas females appear to have higher levels of HMW (18-36 multimers) adiponectin [49]. At the present time, information is lacking as to whether characteristics such as premenopausal versus post-menopausal status as well as other factors relating to the type of women (athleticism, weight, etc.) impact adiponectin levels and multimer forms in females. Hence, further research into these areas, as well as many others noted below, would be valuable.

Whereas adiponectin appears to have a substantial role in obesity, this role is shared as one amongst several important proteins that impact the regulation of insulin sensitization, body weight, endothelial function and anti-inflammatory actions [50-56]. Adiponectin has been described to be involved in the regulation of several key signaling molecules, such as c-Jun $\mathrm{N}$-terminal kinase (JNK), p38 mitogen-activated protein kinases (p38-MAPK), adenosine monophosphate-activated protein kinase (AMPK), peroxisome proliferator-activated receptor a (PPARa) transcription factor and nuclear factor- $\kappa \mathrm{B}(\mathrm{NF}-\kappa \mathrm{B})$, in multiple tissues partly via activation of its receptors (AdipoRs) that include AdipoR1 and AdipoR2, and cell surface protein T-cadherin [57-59]. AdipoR1 and AdipoR2 are both seven-transmembrane domain G-protein Coupled Receptors (GPCRs). However, as they are PAQR (progestin and AdipoQ receptor) family members, their $\mathrm{N}$-terminal end is cytoplasmically embedded within the cell with the C-terminal external to the cell. Additionally, although ubiquitously expressed, whereas AdipoR1 is predominant in muscle and preferentially binds globular adiponectin (in which the collagen-like head domain is proteolytically removed - as in adiponectin trimers), AdipoR2 is abundant in liver and preferentially binds full-length adiponectin (as in HMW-adiponectin). Additionally, T cadherin, a member of the cadherin 
superfamily, has been identified as a potent receptor for both hexameric as well as HMW forms of adiponectin [57, 61-63].

\section{ADIPONECTIN RECEPTORS}

As indicated, AdipoR1/R2 bind unalike adiponectin isoforms with different affinities, and appear to be functionally distinct. Specifically, AdipoR1 has been shown to possess a highaffinity for globular adiponectin and to have a low affinity for full-length adiponectin. In contrast, AdipoR2 binds both isoforms with a reported intermediate affinity [58, 63]. AdipoR1/R2 belong to the functional category of PAQRs that, like some members of this family, possess ceramidase activity [64]. From a physiological perspective, the binding and activation of adiponectin with AdipoR1/2 increases phosphorylation of AMPK, and represses energy-consuming processes such as lipogenesis and gluconeogenesis [59, 63]. A secondary pathway, chiefly activated by adiponectin interactions with AdipoR2, involves regulation of PPARa ligand activity to elevate fatty acid combustion [59, 63]. Both of these pathways are activated under conditions of energy stress, and increase catabolic processes to renew cellular energy.

\section{T-CADHERIN}

T-cadherin is a unique "truncated" cadherin, known as an adiponectin-binding protein, and binds to hexameric and HMW-adiponectin isoforms [57]. It is a $95 \mathrm{kd}$ glycoprotein that differs from other cadherin proteins by lacking both transmembrane and cytoplasmic domains. T-cadherin is anchored, chiefly on the apical surface of the plasma membrane of cells, via a Glycosylphosphatidylinositol (GPI) linkage [60, 62]. T-cadherin by itself is generally considered to have no effect on adiponectin cellular signaling or function, raising the possibility that T-cadherin likely is an adiponectin-binding protein, rather than a receptor. In support of its function as a binding protein, it has been observed that adiponectin accumulates in the circulation at higher than normal levels in T-cadherin-deficient (Tcad$\mathrm{KO})$ mice $[65,66]$. Additionally, heart and vascular tissues lacking T-cadherin become insensitive to adiponectin, even with continued expression of AdipoR1/R2 [66, 67]. Despite the absence of hepatic T-cadherin, liver as the main target tissue for adiponectin also provides support for T-cadherin being an adiponectin-binding protein rather than a functional adiponectin receptor. Additionally, vascular dysfunction and ischemia-induced heart problems have been observed in Tcad-KO mice, similar to adiponectin-deficient mice [66-68].

Genetic studies have shown that the presence of Single Nucleotide Polymorphisms (SNPs) in $C D H 13$, the gene encoding human T-cadherin, can impact adiponectin levels, and hence genetic architecture appears to strongly influence plasma adiponectin concentrations [69,70]. T-cadherin protein expression has been reported to be decreased in endothelial cells of heart and muscle in mice lacking adiponectin [66]. In the light of these findings, T-cadherin may act as a membrane-associated signal transducer for adiponectin. Similar to adiponectin, Tcadherin appears to be plentiful on the surface of some cell types, where it may serve as a low affinity receptor for adiponectin. It may have a co-receptor function to support the appropriate orientation of adiponectin to optimize its interactions with its classical high 
affinity receptors, AdipoR1 or AdipoR2. Irrespective of the mechanism, T-cadherin has been identified as critical for the cardiovascular system protective properties of adiponectin in animal models of cardiac hypertrophy and ischemia-reperfusion [66].

\section{ADIPONECTIN SIGNALING PATHWAYS}

Adiponectin is known to be involved in the activation of several signaling pathways such as NF- $\mathrm{BB}, \mathrm{JNK}$, and signal transducer and activator of transcription (STAT3) (Fig. 2) [71]. In pancreatic $\beta$-cells, cardiomyocytes and hepatocytes [64], adiponectin plays a key role in reducing the expression levels of cellular ceramide with the aid of AdipoR1 and AdipoR2 activation independently from AMPK.

PH domain and leucine zipper containing 1 (APPL1) is an adaptor protein with multiple functional domains. It regulates anti-inflammatory effects, metabolism and cytoprotection through its signaling pathways by interacting directly with AdipoR1/R2 receptors [72-74]. APPL-1 operates signaling pathways with help of a pleckstrin homology domain, a phosphotyrosine domain, and a leucine zipper motif, and is involved in interaction with the $\mathrm{N}$-terminal intracellular region of adiponectin receptors. APPL-1 is also reported to be involved in the regulation of cell proliferation, apoptosis, chromatin remodeling, and endosomal trafficking through direct interaction with membrane receptors and proteins (to present, some 14 proteins are described to bind APPL-1) [75-77]. Additionally, recent studies show evidence that APPL-1 regulates the insulin-signaling pathway [78].

APPL1 is an adaptor protein with multiple functional domains and has been found to interact with AdipoR1 and AdipoR2 to transduce adiponectin-stimulated signaling molecules such as p38 MAPK, AMPK PPAR-a, and RAS-associated protein 5 to downstream targets. Silencing experiments of APPL-1 suggest that adiponectin regulates the activation of AMPK and MAPK in C2C12 myocytes [79]. Additionally, it has also been shown that for RAS-associated protein 5, adiponectin activates a guanine triphosphatase involved in glucose transporter 4 translocation [75]. Several functions, including glucose uptake, adiponectin-activated fatty acid oxidation, and phosphorylation of AMPK, MAPK, and Acetyl-Coenzyme a Carboxylase (ACC) have been reported to decline in deficient myocytes [79]. These studies suggest that APPL-1 plays a key role within the adiponectin signaling cascade. This signaling cascade of adiponectin operates with the aid of its receptors and activation of AMPK via APPL-1. A study by Hardie et al. (2003) shows that an increase in the intracellular AMP/ATP ratio can modulate AMPK [80]. Adiponectin is known to regulate enhancement of insulin via activation of PPAR-a, which leads to an increase in fatty acid combustion and energy consumption [53]. Adi-ponectin's role in the activation of AMPK appears to occur through AdipoR1, whereas activation of PPAR arises via AdipoR2 [81]. Adiponectin-mediated activation of AMPK and enhanced phosphorylation of ACC represent major downstream targets in prostate cancer cell lines LNCaP and CWR22Rv1, and in the liver HepG2 cell line [82]. A study by Imai et al. (2006) showed that overexpression studies of a Dominant-Negative (DN) LKB1 in C2C12 myotubes inhibited adiponectin or AICAR activated AMPK phosphorylation at Thr 172 [138]. 
Adiponectin-activated AMPK has additionally been shown to be involved in inhibition of the mTOR pathway, which is reported over-activated in several cancers, including prostate cancer [83, 84]. An increase in phosphorylation of p70 S6 kinase, and phosphorylation of S6 has been observed in adiponectin-treated prostate cancer cells. Rapamycin-mediated inhibition of phosphorylation of p70 S6 kinase and S6 led to the activation of mTOR through the PI3 kinase/Akt pathway [83, 84].

\section{ADIPONECTIN'S EXPRESSION IN PROSTATE CANCER}

Several studies have indicated an involvement of obesity linked with prostate cancer progression. A meta-analysis study has demonstrated that obesity is weakly correlated with prostate cancer progression [85]. This is supported by a study showing that BMI and weight are associated with prostate cancer [7]. A further study has reported muscle area is linked with prostate cancer [86]. Increased levels of estrogen and progesterone in obese men are reported to inhibit growth and metastasis of prostate cancer [87]. A particularly notable study is that of Goktas et al. (2005) that suggests that decreased levels of adiponectin are associated with prostate cancer, as compared to normal healthy individuals or individuals with benign prostatic hyperplasia, and this study also indicates that decreased levels of adiponectin are associated with increased grades of cancer progression (Fig. 3) [24]. Such investigations are interesting in the light of growing evidence that adiponectin is antiproliferative in prostate cancer cells and inhibits dihydrotestosterone-activated cell proliferation [88], IL-6 [89], and IGF-I [90]. Indeed, a study by Bub et al. (2006) showed that full-length adiponectin attenuates dihydrotestosterone-induced cell growth in $\mathrm{LNCaP}$ androgen-dependent prostate cancer cells [88]. Elevated levels of NADPH oxidase (NOX)2 and NOX4, and decreased amounts of superoxide anion were observed when prostate cancer cell lines were treated with adiponectin. Lu et al., (2006) not only demonstrated an association between adiponectin and prostate cancer [91], but also underlying mechanisms pointing towards a potential link between obesity and prostate oxidative stress. This study demonstrated that adiponectin treatment increased cellular anti-oxidative defense mechanisms and decreased oxidative stress in a significant and dose-dependent manner in human 22Rv1 and DU-145 PC prostate cancer cell lines.

To the contrary, Baillargeon et al. (2008) reported no significant association between adiponectin expression levels and prostate cancer risk and aggressiveness [92], and additionally found no association of prostate cancer with BMI, leptin and IL-6 values. Another study supports a lack of association between Gleason (a microscopic prostate cancer grading system) score and adiponectin serum levels in an evaluation of patients with radical prostatectomy [93], albeit lower adiponectin was independently associated with highgrade prostate cancer. Serum adiponectin levels are reported detectable at higher concentrations in prostate cancer patients with T3 versus T2 stage cancer [28], in which cancer has advanced outside (T3) rather than is confined within the prostate (T2), respectively. This same study notably suggests that cachexia may be a reason for these findings during advanced stages of prostate cancer [28]. Finally, a 25-year prospective study of plasma adiponectin and leptin concentrations and prostate cancer risk and survival demonstrated that men with higher adiponectin concentrations have a lower risk for developing high-grade or metastatic cancer [30]. 
In the light of studies showing that polymorphisms of key genes that encode for insulin and the insulin receptor are associated with a higher risk of prostate cancer, Kaklamani et al. (2011) genotyped selected SNPs within the genes encoding adiponectin (ADIPOQ) and its type I receptor (ADIPORI) to evaluate their association with cancer risk, and reported a significant association in a study of 465 cancer cases and 441 controls [95]. Most of the SNPs genotyped within this study are considered functionally relevant and have been associated with coronary artery disease, T2DM and insulin resistance. A separate study by Beebe-Dimmer et al. (2010) evaluated 10 single SNPs in ADIPOQ and ADIPOR1 genotyped in DNA samples from 131 African American prostate cancer cases and 344 controls, and reported a lack of any association in prostate cancer [96]. Such a difference could arise from the different patient populations and/or the size of the studies, but nevertheless indicate that such analyses are worth following up on. Recently, an investigation indicated that AdipoR2 expression positively correlates with prostate cancer metastasis [94]. Nguyen et al. 2010 also supports involvement of Adipo R2 in prostate cancer progression [46]. In light of this, it would be valuable to gain further information as to how such positive correlations impact prostate cancer development.

\section{ADIPONECTIN'S ANTI-CARCINOGENESIS ACTIVITY}

Several investigations have demonstrated higher expression levels of AdipoR1 and AdipoR2 in several cancers, as well as receptor-mediated action in cancers. As discussed, adiponectin has been shown to be involved in obesity-linked cancers. Evidence supports its role in growth inhibition, but also a role in proliferation [96-101] when colorectal cancer cells are treated with adiponectin. Interestingly, activation of various pro-inflammatory cytokines and an enhancement of growth were observed when HT-29 (human colorectal adenocarcinoma) cells were cultured in the presence of adiponectin [102]. The actions of adiponectin on tumor cells can, in some cases, be regulated by the microenvironment, such as occurs with varying glucose availability. Whereas adiponectin inhibited cell growth in colon cancer cell lines when cultured in glucose-containing medium, it supported cell survival in glucosedeprived medium, with an increase in AdipoR1 and AdipoR2 expression [103]. This is relevant to clinical and in vivo animal studies in which cells within different regions of tumors are often subjected to nutritional stress, and the presence of adiponectin may have divergent actions, particularly in malnourished patients in which glucose levels could readily vary regionally within a tumor. Mechanistically, the survival effect during glucose deprivation was allied with the activation/enhancement of autophagic machinery consequent to AMPKa and PPARa activation and IGF-1/PI3k/Akt/mTOR pathway inhibition [103]. Adiponectin clearly has both direct and indirect actions, and treated colon cancer cells showed down-regulation of COX-2 mRNA expression and up-regulation of T cadherin expression [104].

As discussed, adiponectin exists as a multimeric protein with different isoforms, and a study by Bub et al., (2006) suggests that it is HMW-adiponectin that inhibits cell proliferation of prostate carcinoma cells [88]; albeit other isoforms also have other significant functions. As with all proteins, their time-dependent concentration impacts their actions as do the presence or absence of other key proteins. In a study by Grossmann et al., (2008) the relative ratio between adiponectin and leptin (another key cytokine secreted by adipose tissue that has 
several opposing actions to adiponectin, as it is implicated as a growth-promoting factor for breast cancers) affected adiponectin's ability to inhibit proliferation when MCF7 cells were grown at concentrations in the order of $5 \mu \mathrm{g} / \mathrm{ml}$ for $48 \mathrm{~h}$ [105]. Studies by Treeck et al., (2008) determined that adiponectin levels in the order of $10 \mu \mathrm{g} / \mathrm{ml}$ for 6 days [106] may or may not have activity in similar cell lines depending on the potential presence of factors such as $17-\beta$ estradiol availability as well as on levels of key transcripts (such as caspase 1, $\mathrm{ER} \beta 2$, ER $\beta 5$, TR2 orphan nuclear hormone receptor, and ubiquitin-specific peptidase 2 (USP2)) within the target cells. The globular form of adiponectin has been reported to be associated with colorectal tumors and may also be involved in the activation of genes in the globular adiponectin-AdipoR1-AMPK pathway [107]. In light of these studies, further information is needed in relation to the role of the multiple different forms of adiponectin.

\subsection{Adiponectin's Role in Tumor Angiogenesis}

A number of recent investigations have shown that adiponectin has a pro-angiogenic role in murine models of breast cancer [108, 109]. Increased hypoxia, apoptosis and less vascularized tumor cells were detected in adiponectin-deficient mouse mammary tumor virus-polyoma middle T-antigen (MMTV-PyV-mT) tumors when compared to wild type tumors. A study of tumors that did not responded to anti-angiogenic therapy suggests that the activation of numerous transcriptional pathways is implicated in the regulation of angiogenesis [110]. Studies suggest that the vascular role of adiponectin is likely mediated through T-cadherin. In this regard, MMTV-PyV-mT tumor and ischemic hind-limb models have shown that adiponectin is required in association with T-cadherin for angiogenesis [65, $66,108,111]$. However, adiponectin's role in a tumor environment, as compared to a vascular injury environment, may be different and hence further studies are needed in this area too.

RNA silencing studies have shown that endothelial cell migration and proliferation requires involvement of both AdipoR1/R2 and T-cadherin [66]. Indeed, input from a number of studies has indicated that AdipoR1/R2, activation of AMPK [111], AKT and endothelial nitric oxide synthase (eNOS) [112,118], (MAPK) pathway, and RAS-ERK1/2 [112-114] are necessary to mediate adiponectin-mediated signals that have been reported in endothelial cells. Taken together these studies indicate the role that T-cadherin and AdipoR1/R2 play in regulating angiogenesis in cancer has yet to be fully elucidated. The physiological role of these proteins in the non-cancerous state is perhaps more readily comprehendible in light of the low plasma adiponectin levels known to occur in patients with T2DM in which collateral vessel development is impaired and there is a compromised angiogenic response after ischemic injury as well as poor wound healing. Under such circumstances, adiponectin would appear to have a protective action on the vasculature in part by promoting Akt signaling, an important regulator of angiogenesis and endothelial cell homeostasis [119]. It is important to note that several studies suggest that adiponectin has anti-angiogenic actions in cellular and in vivo studies. Specifically, Brakenhielm et al., (2004) characterized the potent inhibition of endothelial angiogenic events such as migration and proliferation by adiponectin [120]. These appear to involve the MAPK and cAMP-PKA pathways [121]. In chick chorioallantoic membrane and mouse corneal angiogenesis assays, adiponectin inhibited new blood vessel growth, and in a well vascularized mouse T241 fibro-sarcoma 
tumor model adiponectin reduced vascularization and tumor growth [120]. A study by Tae et al., (2014) suggests that adiponectin may be involved in actions promoting anti-angiogenesis in early stages of colon carcinogenesis [104]. The discrepancies among these studies may relate to a number of factors, such as the evaluation of the function of adiponectin and Tcadherin in angiogenesis by the use of knockout, a valuable scientific tool to understand mechanisms but a state that does not exist in humans, to different isoforms of adiponectin, different interacting proteins as well as to the local microenvironment in the models assessed, and thus this area of investigation continues to be worthy of further research.

\section{CLINICAL SIGNIFICANCE OF ADIPONECTIN AND RECEPTORS IN CANCER}

A decline in adiponectin is linked with cancer progression as reported in several cancers, such as leukemia, lymphoma and myeloma, endometrial cancer, breast cancers, prostate cancers, colorectal cancers, liver cancers and gastric cancers [115-117]. Immunohistochemistry analyses have described a decreased expression of AdipoR1 and AdipoR2 receptors in prostate cancerous tissues in comparison to healthy prostate tissue, when 72 cases and 27 non-cases were examined [25]. This study also demonstrated that higher adiponectin levels in serum associated with a decreased risk of prostate cancer. A recent investigation indicated that plasma adiponectin levels are less in KRAS mutant colorectal cancer whereas the plasma adiponectin concentration is normal in KRAS wild type cancer [118] (where the mutant KRAS gene is found in some 35\% to 45\% of colorectal cancers, and its protein product KRAS - also known as p21 - acts as an important molecular on/off switch). The cell surface receptors for AdipoR1 and -R2 are expressed in benign and malignant human prostate tissues, which have a key role in the activation of MAPK, AMPK and NF- $\mathrm{KB}$ signaling pathways $[29,122]$. These studies also suggest that adiponectin and its receptors have a role in the pathophysiology of obesity and prostate cancer through a complex interaction with other hormones and cytokines. Clinical studies strongly support the view that decreased adiponectin levels enhance invasion, malignancy [22] and tumor size (Fig. 4) [123]. In contrast, some recent investigations provide evidence that increased adiponectin levels are correlated with cancer progression, as raised adiponectin levels were reported in a clinical study of pancreatic patients [124]. Elevated levels of adiponectin have additionally been observed in liver cancer with chronic hepatitis C [125]. Hence, recent investigations have raised questions as to whether adiponectin levels are correlated with cancer progression or not, and this controversy is critically evaluated in a recent review by Katira and Tan (2016) [126].

\section{CONCLUSION}

Prostate cancer represents a major health problem with a high mortality rate among the male population of North America and Western Europe [126, 127]. Studies have shown that a high fat and calorie intake, a sedentary existence and a Western lifestyle could be key factors underpinning the pathogenesis of prostate cancer.

Adiponectin, the most abundant adipokine present in human adipose tissue, is associated with several malignancies that include T2DM, obesity, insulin resistance, heart disease and 
several cancers - particularly prostate cancer. As indicated, a high fat diet and sedentary way of life, but also genetic defects, such as polymorphism of adiponectin and its receptors appear to be linked with hypoadiponectinemia with potential to lead to progression of prostate cancer. However, as discussed earlier, this link is not a simple one, since the strength of this association appears to depend on factors that have yet to be fully elucidated, such as the tissue type evaluated, the age and ethnicity of individuals.

Studies have indicated an association between obesity and adiponectin concentrations in prostate carcinogenesis. Adipose tissue concentration levels enhance prostate carcinogenesis. Hence adiponectin's ability to increase insulin sensitivity in combination with its antiproliferative properties could make it a promising potential diagnostic and therapeutic tool in the future treatment of carcinogenesis. Insulin resistance additionally has been linked to prostate cancer progression via alteration of the obesity-sex hormone pathway [128] as well as through non-obesity-related pathways [129]. The molecular mechanism(s) of how adipose can impact prostate cancer progression are yet to be clearly understood. The expansion of adipose tissue in obesity can lead to local tissue dysfunction and is often accompanied by low-grade inflammation, changes in endocrine function and alterations in lipolysis that cause increase delivery and deposition of fatty acids to body tissues. This includes the prostate gland as it is bordered by adipose depots whose close communication might cause dysfunction and impact prostate cancer aggressiveness and progression [130]. Adiponectin appears to have a number of potentially beneficial actions in addition to the direct and in-direct ones previously described for cancer cells, as it not only increases insulin sensitivity in various stromal and epithelial cells but also mitigates atherosclerosis through inhibition of vascular smooth muscle cell and endothelial cell proliferation [51, 126, 131, 132].

There are, nevertheless, several key challenges that need to be resolved to permit routine optimal treatment using adiponectin as a therapeutic approach. These include clarifying the roles of each adiponectin isoform within distinct tissus types and under a range of tumorspecific conditions. The roles of each receptor and their associated signaling pathways within different normal and cancer tissue types additionally require elucidation, as do the microenvironmental molecular conditions that promote adiponectin functioning as a cancer suppressor versus as a promoter. It has become increasingly clear that endogenous adiponectin levels can be manipulated and augmented both by drugs (PPAR $\gamma$ agonists (e.g., thiazolidinediones (TZDs)) and ligands (e.g., bezafibrate and fenofibrate) or the blocking of the renin-angiotensin system $[132,133]$ as well as by lifestyle changes in diet $[134,135]$ and aerobic exercise. These, together with current development of agonists to Adi-poR1/R2 $[136,137]$ continue to drive interest in adiponectin as an important drug target of relevance to a broad number of prevalent human disorders, including prostate cancer.

\section{Acknowledgments}

The authors are hugely grateful to Cindy Clark (Division of Library Services, National Institutes of Health Library) for valuable editorial input. This work was supported in part by the Intramural Research Program, National Institute on Aging, National Institutes of Health. 


\section{References}

1. Kirby RS. The natural history of benign prostatic hyperplasia: what have we learned in the last decade? Urology. 2000; 56:3-6. [PubMed: 11074195]

2. Platz EA, Smit E, Curhan GC, et al. Prevalence of and racial/ethnic variation in lower urinary tract symptoms and noncancer prostate surgery in U.S. men. Urology. 2002; 59:877-83. [PubMed: 12031373]

3. Center MM, Jemal A, Lortet-Tieulent J, et al. International variation in prostate cancer incidence and mortality rates. Eur Urol. 2012; 61:1079-92. [PubMed: 22424666]

4. Fair WR, Fleshner NE, Heston W. Cancer of the prostate: a nutritional disease? Urology. 1997; 50:840-8. [PubMed: 9426711]

5. Bosland MC, Oakley-Girvan I, Whittemore AS. Dietary fat, calories and prostate cancer risk. J Natl Cancer Inst. 1999; 91:489-91. [PubMed: 10088612]

6. Calle EE, Rodriguez C, Walker-Thurmond K, et al. Overweight, obesity, and mortality from cancer in a prospectively studied cohort of U.S. adults. N Engl J Med. 2003; 348:1625-38. [PubMed: 12711737]

7. Andersson SO, Wolk A, Bergstrom R, et al. Body size and prostate cancer: a 20-year follow-up study among 135,006 Swedish construction workers. J Natl Cancer Inst. 1997; 89:385-9. [PubMed: 9060961]

8. Kristal AR, Arnold KB, Schenk JM, et al. Race/ethnicity, obesity, health related behaviors and the risk of symptomatic benign prostatic hyperplasia: results from the Prostate Cancer Prevention Trial. J Urol. 2007; 177:1395-1400. [PubMed: 17382740]

9. Giovannucci E, Rimm EB, Chute CG, et al. Obesity and benign prostatic hyperplasia. Am J Epidemiol. 1994; 140:989-1002. [PubMed: 7527182]

10. Dahle SE, Chokkalingam AP, Gao YT, Deng J, Stanczyk FZ, Hsing AW. Body size and serum levels of insulin and leptin in relation to the risk of benign prostatic hyperplasia. J Urol. 2002; 168:599-604. [PubMed: 12131317]

11. Barb D, Pazaitou-Panayiotou K, Mantzoros CS. Adiponectin: a link between obesity and cancer. Expert Opin Investig Drugs. 2006; 15:917-31.

12. Gavrila A, Chan JL, Yiannakouris N, et al. Serum adiponectin levels are inversely associated with overall and central fat distribution but are not directly regulated by acute fasting or leptin administration in humans: cross-sectional and interventional studies. J Clin Endocrinol Metab. 2003; 88:4823-31. [PubMed: 14557461]

13. Spyridopoulos TN, Petridou ET, Skalkidou A, Dessypris N, Chrou-sos GP, Mantzoros CS. Low adiponectin levels are associated with renal cell carcinoma: a case- control study. Int J Cancer. 2007; 120:1573-8. [PubMed: 17205522]

14. Miyoshi Y, Funahashi T, Kihara S, et al. Association of serum adiponectin levels with breast cancer risk. Clin Cancer Res. 2003; 9:5699-704. [PubMed: 14654554]

15. Mantzoros C, Petridou E, Dessypris N, et al. Adiponectin and breast cancer risk. J Clin Endocrinol Metabol. 2004; 89:1102-7.

16. Petridou E, Mantzoros C, Dessypris N, et al. Plasma adiponectin concentrations in relation to endometrial cancer: a case-control study in Greece. J Clin Endocrinol Metabol. 2003; 88:993-7.

17. Petridou E, Mantzoros CS, Dessypris N, Dikalioti SK, Trichopou-los D. Adiponectin in relation to childhood myeloblastic leukaemia. Br J Cancer. 2006; 94:156-60. [PubMed: 16404369]

18. Dal Maso L, Augustin LS, Karalis A, et al. Circulating adiponectin and endometrial cancer risk. J Clin Endocrinol Metabol. 2004; 89:1160-3.

19. Cust AE, Kaaks R, Friedenreich C, et al. Plasma adiponectin levels and endometrial cancer risk in pre- and post-menopausal women. J Clin Endocrinol Metabol. 2006; 92:255-63.

20. Soliman PT, Wu D, Tortolero-Luna G, et al. Association between adiponectin, insulin resistance, and endometrial cancer. Cancer. 2006; 106:2376-81. [PubMed: 16639730]

21. Korner A, Pazaitou-Panayiotou K, Kelesidis T, et al. Total and high-molecular-weight adiponectin in breast cancer: in vitro and in vivo studies. J Clin Endocrinol Metabol. 2007; 92:1041-8. 
22. Ishikawa M, Kitayama J, Kazama S, et al. Plasma adiponectin and gastric cancer. Clin Cancer Res. 2005; 11(2 Pt 1):466-72. [PubMed: 15701829]

23. Freedland SJ, Sokoll LJ, Platz EA, Mangold LA, Bruzek DJ, Mohr P, Yiu SK, Partin AW. Association between serum adiponectin, and pathological stage and grade in men undergoing radical prostatectomy. J Urol. 2005; 174:1266-70. [PubMed: 16145390]

24. Goktas S, Yilmaz MI, Caglar K, Sonmez A, Kilic S, Bedir S. Prostate cancer and adiponectin. Urology. 2005; 65(6):1168-72. [PubMed: 15922427]

25. Michalakis K, Williams CJ, Mitsiades N, et al. Serum adiponectin concentrations and tissue expression of adiponectin receptors are reduced in patients with prostate cancer: a case control study. Cancer Epidemiology, Biomarkers and Prevention. 2007:16308-13.

26. Michela de Martinoa, Carmen V, Leitnera Sebastian L, et al. Serum Adiponectin Predicts Cancerspecific Survival of Patients with Renal Cell Carcinoma. Kidney Cancer. 2016; 2:197-203.

27. Li H, Stampfer MJ, Mucci L, et al. A 25-year prospective study of plasma adiponectin and leptin concentrations and prostate cancer risk and survival. Clin Chem. 2010; 56:34-43. [PubMed: 19910504]

28. Housa D, Vernerova Z, Heracek J, et al. Adiponectin as a potential marker of prostate cancer progression: studies in organ-confined and locally advanced prostate cancer. Physiol Res. 2008; 57:451-8. [PubMed: 17465703]

29. Mistry T, Digby JE, Chen J, Desai KM, Randeva HS. The regulation of adiponectin receptors in human prostate cancer cell lines. Biochem Biophys Res Commun. 2006; 348(3):832-8. [PubMed: 16899222]

30. Gao Q, Zheng J, Yao X, Peng B. Adiponectin inhibits VEGF-A in prostate cancer cells. Tumour Biol. 2015; 36(6):4287-92. [PubMed: 25586350]

31. Gao Q, Yao X, Zheng J. MiR-323 Inhibits Prostate Cancer Vascularization Through Adiponectin Receptor. Cell Physiol Biochem. 2015; 36:1491-8. [PubMed: 26160610]

32. Scherer PE, Williams S, Fogliano M, et al. A novel serum protein similar to C1q, produced exclusively in adipocytes. J Biol Chem. 1995; 270(45):26746-9. [PubMed: 7592907]

33. Maeda K, Okubo K, Shimomura I, et al. cDNA cloning and expression of a novel adipose specific collagen-like factor, apM1 (AdiPose Most abundant Gene transcript 1). Biochem Biophys Res Commun. 1996; 221(2):286-9. [PubMed: 8619847]

34. Hu E, Liang P, Spiegelman BM. AdipoQ is a novel adipose-specific gene dysregulated in obesity. J Biol Chem. 1996; 271(18):10697-703. [PubMed: 8631877]

35. Shimada K, Miyazaki T, Daida H. Adiponectin and atherosclerotic disease. Clin Chim Acta. 2004; 344:1-12. [PubMed: 15149866]

36. Yoda-Murakami M, Taniguchi M, Takahashi K, et al. Change in expression of GBP28/adiponectin in carbon tetrachloride-administrated mouse liver. Biochem Biophys Res Commun. 2001; 285:372-7. [PubMed: 11444852]

37. Jonsson JR, Moschen AR, Hickman IJ, Richardson MM, Kaser S, Clouston AD, et al. Adiponectin and its receptors in patients with chronic hepatitis C. J Hepatol. 2005; 43:929-936. [PubMed: 16139921]

38. Kaser S, Moschen A, Cayon A, et al. Adiponectin and its receptors in non-alcoholic steatohepatitis. Gut. 2005; 54:117-21. [PubMed: 15591515]

39. Patel JV, Abraheem A, Dotsenko O, et al. Circulating serum adiponectin levels in patients with coronary artery disease: relationship to atherosclerotic burden and cardiac function. J Int Med. 2008; 264:593-8.

40. Chen J, Tan B, Karteris E, et al. Secretion of adiponectin by human placenta: differential modulation of adiponectin and its receptors by cytokines. Diabetologia. 2006; 49:1292-1302. [PubMed: 16570162]

41. Caminos JE, Nogueiras R, Gallego R, et al. Expression and regulation of adiponectin and receptor in human and rat placenta. J Clin Endocrinol Metab. 2005; 90:4276-86. [PubMed: 15855268]

42. Maeda K, Okubo K, Shimomura I, et al. cDNA cloning and expression of a novel adipose specific collagen-like factor, apM1 (AdiPose Most abundant Gene transcript 1). Biochem Biophys Res Commun. 1996; 221(2):286-9. [PubMed: 8619847] 
43. Pajvani UB, Du X, Combs TP, et al. Structure-function studies of the adipocyte-secreted hormone Acrp30/adiponectin. Implications for metabolic regulation and bioactivity. J Biol Chem. 2003; 278(11):9073-85. [PubMed: 12496257]

44. Lara-Castro C, Luo N, Wallace P, et al. Adiponectin multimeric complexes and the metabolic syndrome trait cluster. Diabetes. 2006; 55(1):249-59. [PubMed: 16380500]

45. Vasseur F, Meyre D, Froguel P. Adiponectin, type 2 diabetes and the metabolic syndrome: lessons from human genetic studies. Expert Rev Mol Med. 2006; 8(27):1-12.

46. Nguyen PL, Ma J, Chavarro JE, et al. Fatty acid synthase polymorphisms, tumor expression, body mass index, prostate cancer risk, and survival. J Clin Oncol. 2010; 28(25):3958-64. [PubMed: 20679621]

47. Halberg N, Schraw TD, Wang ZV, et al. Systemic fate of the adipocyte-derived factor adiponectin. Diabetes. 2009; 58(9):1961-70. [PubMed: 19581422]

48. Richards AA, Colgrave ML, Zhang J, et al. Sialic acid modification of adiponectin is not required for multimerization or secretion but determines half-life in circulation. Mol Endocrinol. 2010; 24(1):229-39. [PubMed: 19855092]

49. Ye R, Scherer PE. Adiponectin, driver or passenger on the road to insulin sensitivity? Mol Metab. 2013; 2(3):133-41. [PubMed: 24049728]

50. Ouchi N, Kihara S, Arita Y, et al. Novel modulator for endothelial adhesion molecules Adipocyte-derived plasma protein adiponectin. Circulation. 1999; 100:2473-76. [PubMed: 10604883]

51. Fruebis J, Tsao TS, Javorschi S, et al. Proteolytic cleavage product of 30-kDa adipocyte complement-related protein increases fatty acid oxidation in muscle and causes weight loss in mice. Proc Natl Acad Sci USA. 2001; 98:2005-10. [PubMed: 11172066]

52. Berg AH, Combs TP, Du X, Brownlee M, Scherer PE. The adipocyte-secreted protein Acrp30 enhances hepatic insulin action. Nat Med. 2001; 7:947-53. [PubMed: 11479628]

53. Yamauchi T, Kamon J, Waki H, et al. The fat-derived hormone adiponectin reverses insulin resistance associated with both lipoatrophy and obesity. Nat Med. 2001; 7:941-6. [PubMed: 11479627]

54. Whitehead JP, Richards AA, Hickman IJ, Macdonald GA, Prins JB. Adiponectin - a key adipokine in the metabolic syndrome. Diabetes Obes Metab. 2006; 8:264-80. [PubMed: 16634986]

55. Okamoto Y, Kihara S, Ouchi N, et al. Adiponectin reduces atherosclerosis in apolipoprotein Edeficient mice. Circulation. 2002; 106:2767-70. [PubMed: 12451000]

56. Kang KH, Higashino A, Kim HS, Lee YT, Kageyama T. Molecular cloning, gene expression, and tissue distribution of adiponectin and its receptors in the Japanese monkey, Macaca fuscata. J Med Primatol. 2009; 38:77-85. [PubMed: 19367731]

57. Hug C, Wang J, Ahmad NS, Bogan JS, Tsao TS, Lodish HF. T-cadherin is a receptor for hexameric and high-molecular-weight forms of Acrp30/adiponectin. Proc Natl Acad Sci USA. 2004; 101:10308-13. [PubMed: 15210937]

58. Yamauchi T, Kamon J, Ito Y, et al. Cloning of adiponectin receptors that mediate antidiabetic metabolic effects. Nature. 2003; 423:762-9. [PubMed: 12802337]

59. Tang YT, Hu TH, Arterburn M, et al. PAQR proteins: a novel membrane receptor family defined by an ancient 7-transmembrane pass motif. J Mol Evol. 2005; 61:372-80. [PubMed: 16044242]

60. Ranscht B, Dours-Zimmermann MT. T-cadherin, a novel cadherin cell adhesion molecule in the nervous system lacks the conserved cytoplasmic region. Neuron. 1991; 7(3):391-402. [PubMed: 1654948]

61. Vestal DJ, Ranscht B. Glycosyl phosphatidylinositol--anchored T-cadherin mediates calciumdependent, homophilic cell adhesion. J Cell Biol. 1992; 119(2):451-61. [PubMed: 1400585]

62. Ranscht B, Bradshaw R, Dennis E. Cadherins: Interactions and Regulation of Adhesivity. Handbook in Cell Signaling. 2003:889-99.

63. Yamauchi T, Kadowaki T. Adiponectin receptor as a key player in healthy longevity and obesityrelated diseases. Cell Metab. 2013; 17(2):185-96. [PubMed: 23352188]

64. Holland WL, Miller RA, Wang ZV, et al. Receptor-mediated activation of ceramidase activity initiates the pleiotropic actions of adiponectin. Nat Med. 2011; 17(1):55-63. [PubMed: 21186369] 
65. Hebbard LW, Garlatti M, Young LJ, et al. T-cadherin supports angiogenesis and adiponectin association with the vasculature in a mouse mammary tumor model. Cancer Res. 2008; 68(5): 1407-16. [PubMed: 18316604]

66. Parker-Duffen JL, Nakamura K, Silver M, et al. T-cadherin is essential for adiponectin-mediated revascularization. J Biol Chem. 2013; 288(34):24886-97. [PubMed: 23824191]

67. Denzel MS, Scimia MC, Zumstein PM, et al. T-cadherin is critical for adiponectin-mediated cardioprotection in mice. J Clin Invest. 2010; 120(12):4342-52. [PubMed: 21041950]

68. Tyrberg B, Miles P, Azizian KT, et al. T-cadherin (Cdh13) in association with pancreatic $\beta$-cell granules contributes to second phase insulin secretion. Islets. 2011; 3(6):327-37. [PubMed: 21975561]

69. Wu Y, Li Y, Lange EM, et al. Genome-wide association study for adiponectin levels in Filipino women identifies CDH13 and a novel uncommon haplotype at KNG1-ADIPOQ. Hum Mol Genet. 2010; 19(24):4955-64. [PubMed: 20876611]

70. Morisaki H, Yamanaka I, Iwai N, et al. CDH13 gene coding T-cadherin influences variations in plasma adiponectin levels in the Japanese population. Hum Mutat. 2012; 33(2):402-10. [PubMed: 22065538]

71. Miyazaki T, Bub JD, Uzuki M, et al. Adiponectin activates c-Jun NH2-terminal kinase and inhibits signal transducer and activator of transcription 3. Biochem Biophys Res Commun. 2005; 333(1): 79-87. [PubMed: 15936715]

72. Buechler C, Wanninger J, Neumeier M. Adiponectin receptor binding proteins-recent advances in elucidating adiponectin signaling pathways. FEBS Lett. 2010; 584:4280-6. [PubMed: 20875820]

73. Brochu-Gaudreau K, Rehfeldt C, Blouin R, Bordignon V, Murphy BD, Palin MF. Adiponectin action from head to toe. Endocrine. 2010; 37:11-32. [PubMed: 20963555]

74. Deepa SS, Dong LQ. APPL1: role in adiponectin signaling and beyond. Am J Physiol Endocrinol Metab. 2009; 296:E22-E36. [PubMed: 18854421]

75. Schenck A, Goto-Silva L, Collinet C, et al. The endosomal protein Appl1 mediates Akt substrate specificity and cell survival in vertebrate development. Cell. 2008; 133:486-97. [PubMed: 18455989]

76. Liu J, Yao F, Wu R, et al. Mediation of the DCC apoptotic signal by DIP13 a. J Biol Chem. 2002; 277:26281-5. [PubMed: 12011067]

77. Miaczynska M, Christoforidis S, Giner A, et al. APPL proteins link Rab5 to nuclear signal transduction via an endosomal compartment. Cell. 2004; 116:445-56. [PubMed: 15016378]

78. Ryu J, Galan AK, Xin X, et al. APPL1 potentiates insulin sensitivity by facilitating the binding of IRS1/2 to the insulin receptor. Cell Rep. 2014; 7(4):1227-38. [PubMed: 24813896]

79. Mao X, Kikani CK, Riojas RA, et al. APPL1 binds to adiponectin receptors and mediates adiponectin signaling and function. Nat Cell Biol. 2006; 8:516-23. [PubMed: 16622416]

80. Hardie DG, Scott JW, Pan DA, Hudson ER. Management of cellular energy by the AMP-activated protein kinase system. FEBS Lett. 2003; 546:113-20. [PubMed: 12829246]

81. Yamauchi T, Nio Y, Maki T, et al. Targeted disruption of AdipoR1 and AdipoR2 causes abrogation of adiponectin binding and metabolic actions. Nat Med. 2007; 13:332-9. [PubMed: 17268472]

82. Barb D, Neuwirth A, Mantzoros CS, Balk SP. Adiponectin signals in prostate cancer cells through Akt to activate the mammalian target of rapamycin pathway. Endocrine-Related Cancer. 2007; 14:995-1005. [PubMed: 18045951]

83. Cheng SW, Fryer LG, Carling D, Shepherd PR. Thr2446 is a novel mammalian target of rapamycin (mTOR) phosphorylation site regulated by nutrient status. Journal of Biological Chemistry. 2004; 279:15719-22. [PubMed: 14970221]

84. Luo Z, Saha AK, Xiang X, Ruderman NB. AMPK the metabolic syndrome and cancer. Trends in Pharmacological Sciences. 2005; 26:69-76. [PubMed: 15681023]

85. MacInnis RJ, English DR. Body size and composition and prostate cancer risk: systematic review and meta-regression analysis. Cancer Causes Control. 2006; 17(8):989-1003. [PubMed: 16933050]

86. Severson RK, Grove JS, Nomura AM, Stemmermann GN. Body mass and prostatic cancer: a prospective study. BMJ. 1988; 297(6650):713-5. [PubMed: 3147735] 
87. Daniell HW. A worse prognosis for men with testicular atrophy at therapeutic orchiectomy for prostate carcinoma. Cancer. 1998; 83(6):1170-3. [PubMed: 9740082]

88. Bub JD, Miyazaki T, Iwamoto Y. Adiponectin as a growth inhibitor in prostate cancer cells. Biochem Biophys Res Commun. 2006; 340(4):1158-66. [PubMed: 16403434]

89. Fenton JI, Birmingham JM. Adipokine regulation of colon cancer: adiponectin attenuates interleukin-6-induced colon carcinoma cell proliferation via STAT-3. MolCarcinog. 2010; 49:7009.

90. Li G, Cong L, Gasser J, Zhao J, Chen K, Li F. Mechanisms underlying the anti-proliferative actions of adiponectin in human breast cancer cells, MCF7-dependency on the cAMP/protein kinase-A pathway. Nutr Cancer. 2011; 63:80-8. [PubMed: 21108124]

91. Lu JP, Hou ZF, Duivenvoorden WC, et al. Adiponectin inhibits oxidative stress in human prostate carcinoma cells. Prostate Cancer Prostatic Dis. 2012; 15(1):28-35. [PubMed: 22249290]

92. Baillargeon J, Platz EA, Rose DP, et al. Obesity, adipokines, and prostate cancer in a prospective population-based study. Cancer Epidemiol Biomarkers Prev. 2006; 15:1331-5. [PubMed: 16835332]

93. Sher DJ, Oh WK, Jacobus S, Regan MM, Lee GS, Mantzoros C. Relationship between serum adiponectin and prostate cancer grade. Prostate. 2008; 68:1592-8. [PubMed: 18646046]

94. Rider JR, Fiorentino M, Kelly R, et al. Tumor expression of adiponectin receptor 2 and lethal prostate cancer. Carcinogenesis. 2015; 36(6):639-47. [PubMed: 25863129]

95. Kaklamani V, Yi N, Zhang K, et al. Polymorphisms of ADIPOQ and ADIPOR1 and prostate cancer risk. Metabolism. 2011; 60:1234-43. [PubMed: 21397927]

96. Beebe-Dimmer JL, Zuhlke KA, Ray AM, Lange EM, Cooney KA. Genetic variation in adiponectin (ADIPOQ) and the type 1 receptor (ADIPOR1), obesity and prostate cancer in African Americans. Prostate Cancer Prostatic Dis. 2010; 13:362-8. [PubMed: 20697428]

97. Kim AY, Lee YS, Kim KH, et al. Adiponectin represses colon cancer cell proliferation via AdipoR1- and -R2-mediated AMPK activation. Mol Endocrinol. 2010; 24:1441-52. [PubMed: 20444885]

98. Byeon JS, Jeong JY, Kim MJ, et al. Adiponectin and adiponectin receptor in relation to colorectal cancer progression. Int J Cancer. 2010; 127:2758-67. [PubMed: 21351255]

99. Sugiyama M, Takahashi H, Hosono K, et al. Adiponectin inhibits colorectal cancer cell growth through the AMPK/mTOR pathway. Int J Oncol. 2009; 34:339-44. [PubMed: 19148467]

100. Williams CJ, Mitsiades N, Sozopoulos E, et al. Adiponectin receptor expression is elevated in colorectal carcinomas but not in gastrointestinal stromal tumors. Endocr Relat Cancer. 2008; 15:289-99. [PubMed: 18310295]

101. Zakikhani M, Dowling RJ, Sonenberg N, Pollak MN. The effects of adiponectin and metformin on prostate and colon neoplasia involve activation of AMP-activated protein kinase. Cancer Prev Res (Phila). 2008; 1:369-75. [PubMed: 19138981]

102. Ogunwobi OO, Beales IL. Adiponectin stimulates proliferation and cytokine secretion in colonic epithelial cells. Regul Pept. 2006; 134:105-13. [PubMed: 16529829]

103. Habeeb BS, Kitayama J, Nagawa H. Adiponectin supports cell survival in glucose deprivation through enhancement of autophagic response in colorectal cancer cells. Cancer Sci. 2011; 102:999-1006. [PubMed: 21299716]

104. Tae CH, Kim SE1, Jung SA, et al. Involvement of adiponectin in early stage of colorectal carcinogenesis. BMC Cancer. 2014; 14:811. [PubMed: 25370174]

105. Grossmann ME, Ray A, Dogan S, Mizuno NK, Cleary MP. Balance of adiponectin and leptin modulates breast cancer cell growth. Cell Res. 2008; 18:1154-6. [PubMed: 18957939]

106. Treeck O, Lattrich C, Juhasz-Boess I, Buchholz S, Pfeiler G, Ortmann O. Adiponectin differentially affects gene expression in human mammary epithelial and breast cancer cells. $\mathrm{Br} \mathbf{J}$ Cancer. 2008; 99:1246-50. [PubMed: 18827813]

107. Vetvik KK, Sonerud T, Lindeberg M, et al. Globular adiponectin and its downstream target genes are up-regulated locally in human colorectal tumors: ex vivo and in vitro studies. Metabolism. 2014; 63(5):672-81. [PubMed: 24636346] 
108. Denzel MS, Hebbard LW, Shostak G, Shapiro L, Cardiff RD, Ranscht B. Adiponectin deficiency limits tumor vascularization in the MMTV-PyV-mT mouse model of mammary cancer. Clin Cancer Res. 2009; 15(10):3256-64. [PubMed: 19447866]

109. Landskroner-Eiger S, Qian B, Muise ES, et al. Proangiogenic contribution of adiponectin toward mammary tumor growth in vivo. Clin Cancer Res. 2009; 15(10):3265-76. [PubMed: 19447867]

110. Bergers G, Hanahan D. Modes of resistance to anti-angiogenic therapy. Nat Rev Cancer. 2008; 8(8):592-603. [PubMed: 18650835]

111. Shibata R, Ouchi N, Ito M, et al. Adiponectin-mediated modulation of hypertrophic signals in the heart. Nature Medicine. 2004; 10:1384-9.

112. Ouchi N, Kobayashi H, Kihara S, et al. Adiponectin stimulates angiogenesis by promoting crosstalk between AMP-activated protein kinase and Akt signaling in endothelial cells. Journal of Biological Chemistry. 2004; 279:1304-9. [PubMed: 14557259]

113. Lee MH, Klein RL, El-Shewy HM, et al. The adiponectin receptors AdipoR1 and AdipoR2 activate ERK1/2 through a Src/Ras-dependent pathway and stimulate cell growth. Biochemistry. 2008; 47(44):11682-11692. [PubMed: 18842004]

114. Li FY, Cheng KK, Lam KS, et al. Cross-talk between adipose tissue and vasculature: role of adiponectin. Acta Physiol (Oxf). 2011; 203(1):167-80. [PubMed: 21062420]

115. Dalamaga M, Diakopoulos KN, Mantzoros CS. The role of adiponectin in cancer: a review of current evidence. Endocr Rev. 2012; 33(4):547-94. [PubMed: 22547160]

116. Hefetz-Sela S, Scherer PE. Adipocytes: impact on tumor growth and potential sites for therapeutic intervention. Pharmacol Ther. 2013; 138(2):197-210. [PubMed: 23353703]

117. Mauro L, Naimo GD, Ricchio E, Panno ML, Andò S. Cross-Talk between Adiponectin and IGFIR in Breast Cancer. Front Oncol. 2015; 5:157. [PubMed: 26236690]

118. Inamura K, Song M, Jung S, et al. Prediagnosis Plasma Adiponectin in Relation to Colorectal Cancer Risk According to KRAS Mutation Status. J Natl Cancer Inst. 2015; 108(4)

119. Shiojima I, Walsh K. Role of Akt signaling in vascular homeostasis and angiogenesis. Circ Res. 2002; 90:1243-50. [PubMed: 12089061]

120. Brakenhielm E, Veitonmaki N, Cao R, et al. Adiponectin-induced antiangiogenesis and antitumor activity involve caspase-mediated endothelial cell apoptosis. PNAS. 2004; 101:2476-81.

[PubMed: 14983034]

121. Mahadev K, Wu X, Donnelly S, Ouedraogo R, Eckhart AD, Goldstein BJ. Adiponectin inhibits vascular endothelial growth factor-induced migration of human coronary artery endothelial cells. Cardiovascular Res. 2008; 78:376-84.

122. Kelesidis I, Kelesidis T, Mantzoros CS. Adiponectin and cancer: a systematic review. Br J Cancer. 2006; 94(9):1221-5. [PubMed: 16570048]

123. Otake S, Takeda H, Suzuki Y, et al. Association of visceral fat accumulation and plasma adiponectin with colorectal adenoma: evidence for participation of insulin resistance. Clin Cancer Res. 2005; 11(10):3642-6. [PubMed: 15897559]

124. Dalamaga M, Migdalis I, Fargnoli JL, et al. Pancreatic cancer expresses adiponectin receptors and is associated with hypoleptinemia and hyperadiponectinemia: a case-control study. Cancer Causes Control. 2009; 20(5):625-33. [PubMed: 19051043]

125. Arano T, Nakagawa H, Tateishi R, et al. Serum level of adiponectin and the risk of liver cancer development in chronic hepatitis C patients. Int J Cancer. 2011; 129(9):2226-35. [PubMed: 21170963]

126. Katira A, Tan PH. Evolving role of adiponectin in cancer-controversies and update. Cancer Biol Med. 2016; 13(1):101-19. [PubMed: 27144066]

127. Miller, B.Ries, L.Henkey, B., Edwards, B., editors. Cancer Statistics Review 1973-1989. National Cancer Institute; Bethesda, Maryland: 1992. NIH Publication No. 92-2789

128. Flanders WD. Review: prostate cancer epidemiology. Prostate. 1984; 5:621-9. [PubMed: 6387660]

129. Hsing AW1, Tsao L, Devesa SS. International trends and patterns of prostate cancer incidence and mortality. Int J Cancer. 2000; 85(1):60-7. [PubMed: 10585584] 
130. Taylor RA, Lo J, Ascui N, Watt MJ. Linking obesogenic dysregulation to prostate cancer progression. Endocr Connect. 2015; 4:R68-80. [PubMed: 26581226]

131. Amling CL. The association between obesity and the progression of prostate and renal cell carcinoma. Urol Oncol. 2004; 22(6):478-84. [PubMed: 15610865]

132. Ouchi N, Kihara S, Funahashi T, Matsuzawa Y, Walsh K. Obesity, adiponectin and vascular inflammatory disease. Curr Opin Lipidol. 2003; 14(6):561-6. [PubMed: 14624132]

133. Hossain MM, Mukheem A, Kamarul T. The prevention and treatment of hypoadiponectinemiaassociated human diseases by up-regulation of plasma adiponectin. Life Sci. 2015; 135:55-67. [PubMed: 25818192]

134. Silva FM, de Almeida JC, Feoli AM. Effect of diet on adiponectin levels in blood. Nutr Rev. 2011; 69:599-612. [PubMed: 21967160]

135. Fragopoulou E, Panagiotakos DB, Pitsavos C, et al. The association between adherence to the Mediterranean diet and adiponectin levels among healthy adults: the ATTICA study. J Nutr Biochem. 2010; 21:285-9. [PubMed: 19369051]

136. Kriketos AD, Gan SK, Poynten AM, Furler SM, Chisholm DJ, Campbell LV. Exercise increases adiponectin levels and insulin sensitivity in humans. Diabetes Care. 2004; 27:629-30. [PubMed: 14747265]

137. Holland W, Scherer P. Ronning after the adiponectin receptors. Science. 2013; 342:1460-61. [PubMed: 24357309]

138. Imai K, Inukai K, Ikegami Y, Awata T, Katayama S. LKB1, an upstream AMPK kinase, regulates glucose and lipid metabolism in cultured liver and muscle cells. Biochem Biophys Res Commun. 2006; 351:595-601. [PubMed: 17083919] 


\section{BOTTOM LINE}

- $\quad$ Adiponectin is a key protein generated and secreted by adipocytes that is important in regulating insulin sensitization, body weight, endothelial function and anti- inflammatory actions.

- $\quad$ Adiponectin is involved in insulin sensitizing effects by activation of signaling pathways, such as p38 MAPK, AMPK PPAR-a, and RAS-associated protein 5 with the help of APPL-1.

- $\quad$ BMI and weight are associated with a higher risk of several cancers, and a growing literature suggests that this includes prostate cancer.

- Dysregulation of AdipoR1 and AdipoR2 receptor expression appears to be associated with prostate cancerous tissues.

- Longitudinal studies defining time-dependent changes in adiponectin levels in the development of human cancers as well as other conditions - obesity and metabolic syndrome - will aid in evaluating the potential of the agent as a disease bio-marker.

- Further research of defined isoforms of adiponectin and selective receptor agonists/antagonists will aid define how adiponectin signaling pathways can best be utilized to maintain health. 


\section{APN's Structure}
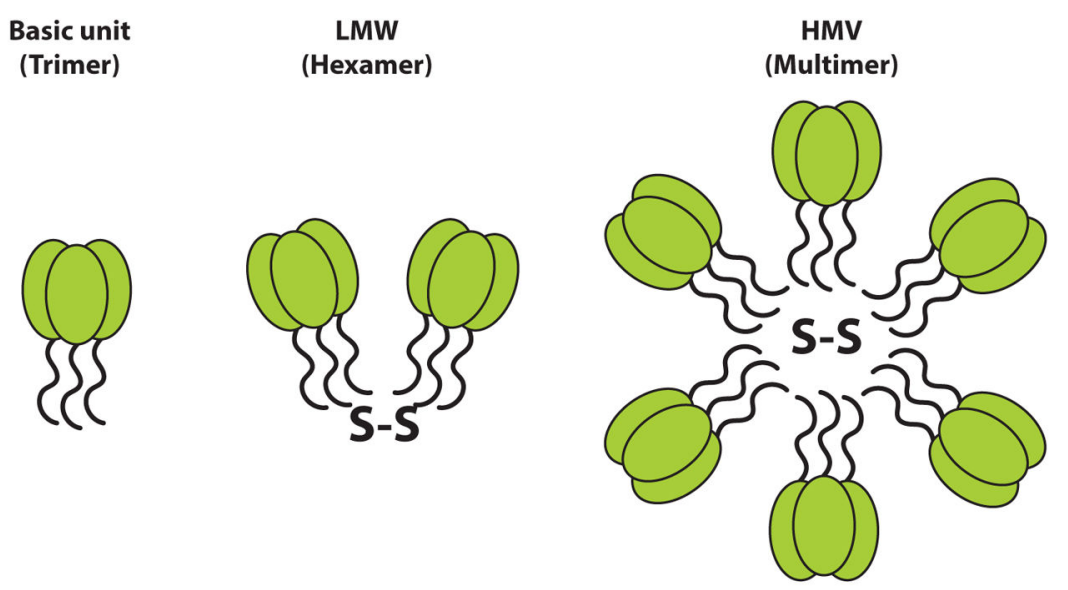

Globular

Fig. (1).

Adiponectins (APNs) exists in different isoforms, as depicted schematically, and each fulllength adiponectin (composed of 244 amino acids) has a $\mathrm{N}$-terminal collagen-like fibrous domain as well as a C1q-like globular domain at the $\mathrm{C}$-terminus. Three adiponectin monomers combine to provide a trimeric isoform that is considered to be the basic building block for higher oligomers. Disulfide bonding allows generation of low molecular weight (LMW) and high molecular weight (HMW) complexes. A smaller adiponectin form, consisting of the globular domain alone, exists in plasma in small amounts. 


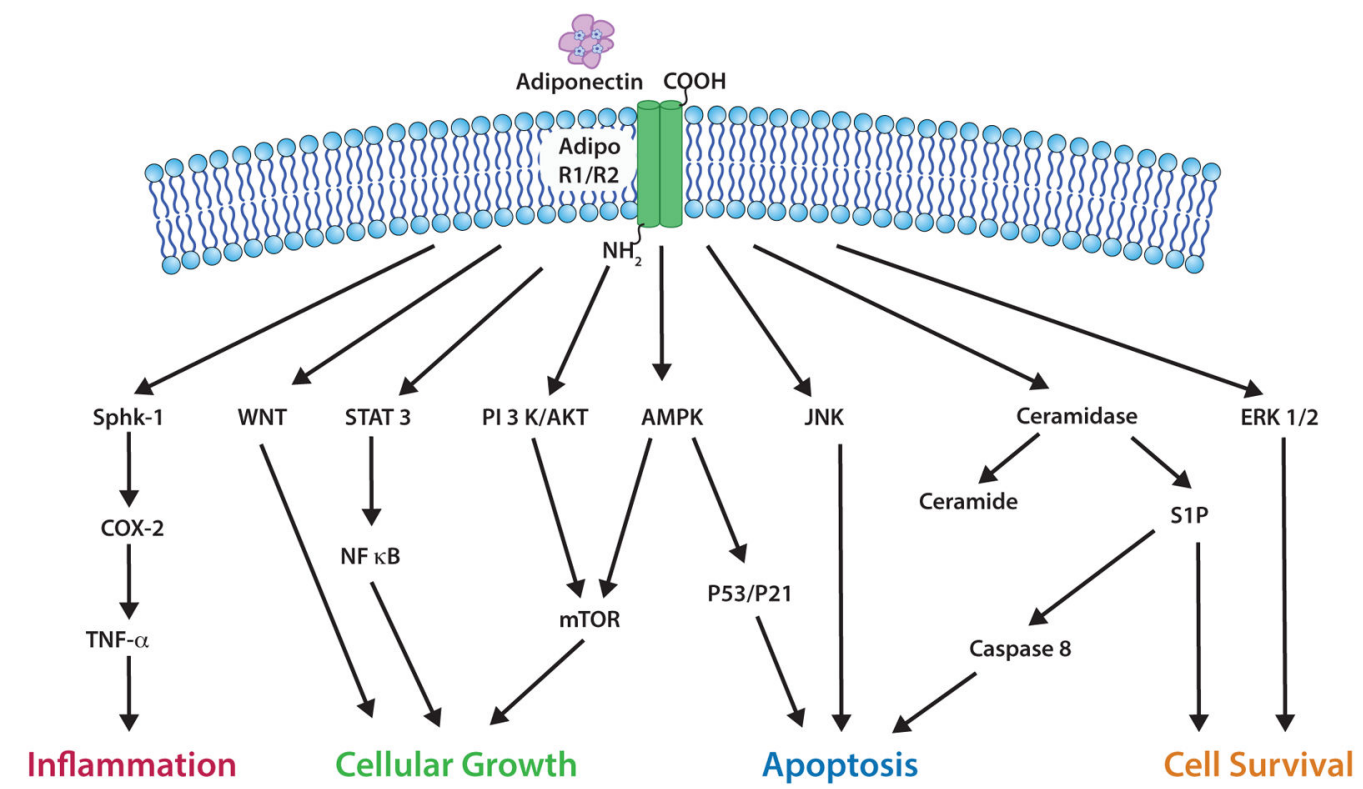

Fig. (2).

Adiponectin is involved in signaling pathways relevant to cancer tissues. By binding to AdipoR1 and AdipoR2, adiponectin can initiate a cascade of signaling events such as by activation of AMPK and other shown key regulatory proteins to instigate a variety of actions. For example, anti-apoptotic actions are mediated via the activation of ceramidase, Akt, and AMPK as well as via the supression of ERK1/2, PI3K/Akt, Wnt/ $\beta$-catenin, NF- $\kappa$ B, JNK and the cell cycle regulators p53/p21, and additionally by negatively influencing the mTOR/S6K axis and fatty acid synthase. Adiponectin can mediate inflammation by activation of sphingosine kinase-1 (Sphk1) and cyclooxygenase-2 (COX-2). 
Normal Periprostatic Tissue

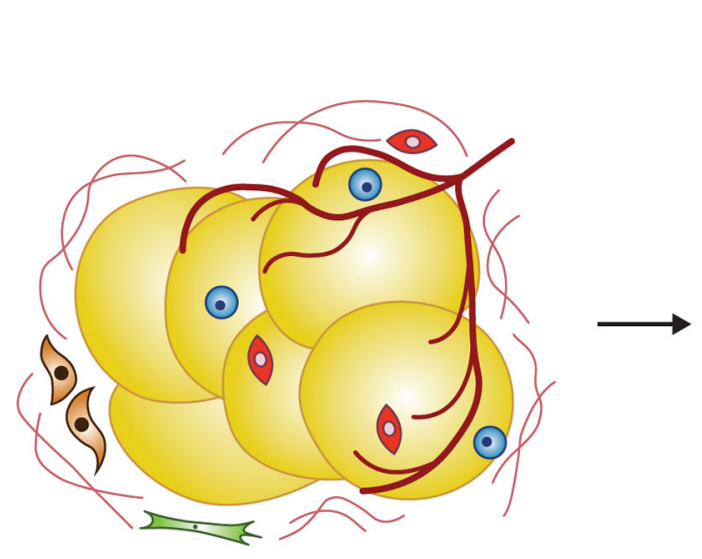

Obese Periprostatic Tissue

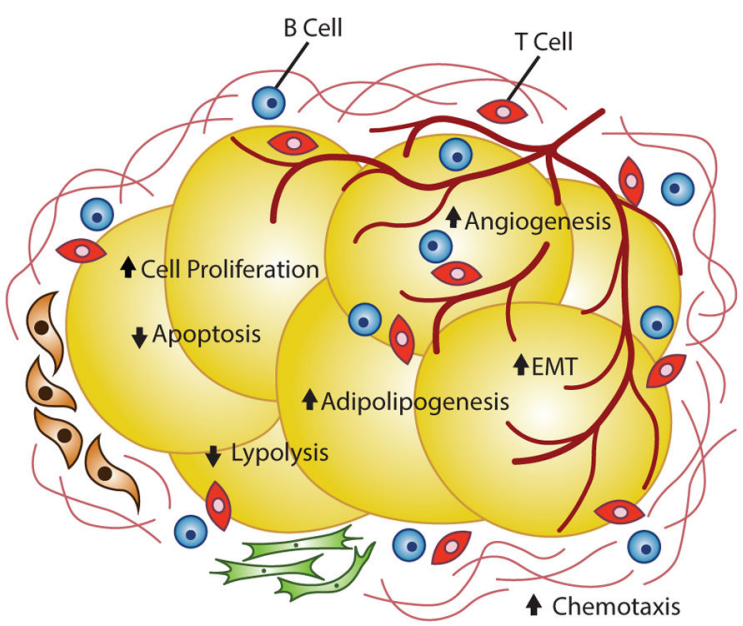

\section{Prostate Cancer Progression}

Fig. (3).

Schematic diagram of prostate adipose tissue changes in the obese patient with prostate cancer. Dysregulated gene expression results in fatty mass accumulation and increased hypercellularity that can lead to prostate cancer progression. 
High Adiponectin

Low Adiponectin
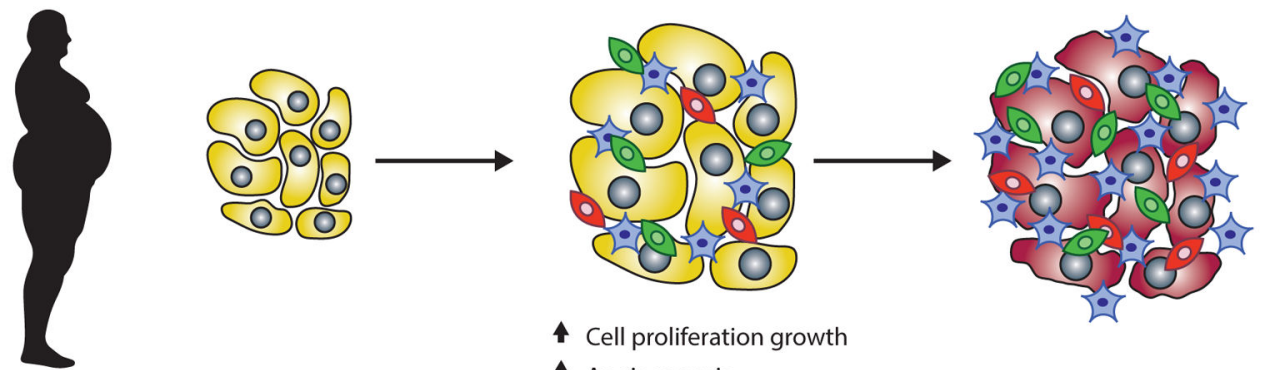

4 Cell proliferation growth

4 Angiogenesis

4 Adipo lipo genes

$\uparrow$ EMT

$\downarrow$ Apoptosis

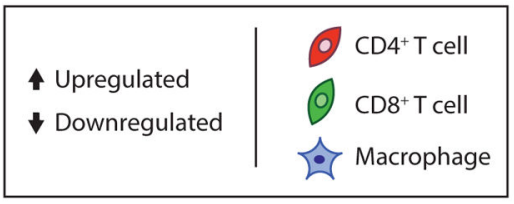

Fig (4).

Obesity and cancer: a decrease in adiponectin is associated with cancer progression. 